\title{
ANÁLISE DA (IN)CONSTITUCIONALIDADE DO REGIME DISCIPLINAR DIFERENCIADO E O PRINCÍPIO DA DIGNIDADE DA PESSOA HUMANA.
}

\section{Maria Fernanda Paci Hirata Shimada Heloisa Helena Silva Pancotti}

\section{RESUMO}

O presente estudo pretende refletir sobre a sistemática do Regime Disciplinar Diferenciado (RDD) no tocante à (in) observância ao Princípio da Dignidade da Pessoa Humana. Sendo assim, é certo que devido a atual realidade da estrutura do sistema carcerário brasileiro, tornou-se essencial a criação de uma Lei que regulasse e atribuísse aos presos de maior periculosidade imposições de regras mais rígidas. Portanto o RDD não viola a Constituição, constituindo forma proporcional de resposta penal em casos graves, que, ao contrário de ofender, concretiza a garantia constitucional da individualização da pena, dentro da liberdade de conformação deixada ao legislador ordinário.

Palavras-Chave: Direito; Constituição Federal; Direito Penal; Princípios.

\section{ANALYSIS OF THE (IN) CONSTITUTIONALITY OF THE DIFFERENTIATED DISCIPLINARY REGIME AND THE PRINCIPLE OF THE DIGNITY OF THE HUMAN PERSON.}

\begin{abstract}
The present study reflects on the systematics of the Differentiated Disciplinary Regime (DDR) regarding the (in) compliance with the Principle of the Dignity of the Human Person. Therefore, true that due to the current reality of the structure of the brazilian prison system, essential create laws that would regulate and assign the most dangerous prisoners the imposition of stricter rules. Therefore, RDD does not violate the Constitution, beying a proportional response in serious cases, which, contrary to offense, concretizes the constitutional guarantee of the individualization of the sentence, within the freedom of conformation to the ordinary legislator.
\end{abstract}

Keywords: Law; Federal Constitution; Criminal Law; Principles.

\footnotetext{
Maria Fernanda Paci. Mestranda em Direito pelo Centro Universitário Eurípides de Marília (UNIVEM). Especialista em Direito do Trabalho e Processo do Trabalho -Anhanguera. Grandes Transformações Processuais-UNISUL. Graduada em Direito pela Universidade Federal de Mato Grosso do Sul. Coordenadora na Etec Sebastiana Augusta de Moraes Andradina/SP. Docente do Curso de Direito em Direito Penal da Universidade Brasil - Andradina/SP. Advogada Criminal e Civilista. Residente na Rua Antônio Rodrigues de Carvalho, 888, Jardim Sampaio, Mirandópolis/SP. E-mail: mferpaci@yahoo.com.br.

Heloisa Helena Silva Pancotti: Graduada em Direito pelo Centro Universitário Toledo. Especialista em Direito Processual pela mesma IES. Atuou na OAB-Mulher da $68^{\circ}$ Subseção de Birigui/SP. Advogada autônoma. Mestre em Direito pelo UNIVEM de Marília. Membro do Grupo de Pesquisa INPP- A intervenção do Poder Público na Vida da Pessoa. Se dedica a pesquisar Direitos Sociais com ênfase em sua interseccionalidade com a questão de gênero. Residente na Rua Nove de Julho, 893.Centro, Birigui, SP. E-mail: hpancotti@gmail.com.
} 


\section{INTRODUÇÃO}

A importância dada ao presente tema, atualmente, ganha cada vez mais atenção, tanto dos operadores do direito, quanto da própria sociedade, haja vista que guardam relação direta com os direitos e garantias constitucionais preconizadas pela Constituição da República e, assim, com o Estado Democrático de Direito, em especial ao Principio da Dignidade da Pessoa Humana.

É certo que devido a atual realidade da estrutura do sistema carcerário brasileiro e visando o combate aos poderosos grupos criminosos, tornou-se essencial a criação de uma Lei que regulasse e atribuísse aos presos de maior periculosidade imposições de regras mais rígidas que dificultasse o acesso ao mundo exterior e contribuísse no combate ao crime, assim como impedisse o desequilíbrio da ordem carcerária.

Nesse diapasão, o presente estudo pretende refletir sobre a sistemática do Regime Disciplinar Diferenciado (RDD) no tocante à (in) observância ao Princípio da Dignidade da Pessoa Humana, com vistas a avaliar se a Lei 10.792, de 01/12/2003, ao impor um regime de confinamento diferenciado a um ser humano, se não estaria infringindo o direito fundamental da dignidade da pessoa, corolário da Constituição Brasileira de 1988. Tal análise utilizou a pesquisa bibliográfica, por meio do procedimento dedutivo.

O trabalho foi dividido em três partes: o Princípio da Dignidade da Pessoa Humana; o Regime Disciplinar Diferenciado e posições doutrinárias sobre à implementação do regime disciplinar diferenciado no sistema penitenciário brasileiro.

Nessa esteira, o trabalho é justificável e importante, pois visa, primordialmente, esclarecer, educar e refletir sobre um tema tão controverso, que gera acirradas discussões doutrinarias e jurisprudências, de modo a suscitar uma resposta sobre a constitucionalidade ou não do Regime Disciplinar Diferenciado frente o Princípio da Dignidade da Pessoa Humana, e a efetiva consequência social na sua aplicação.

Conclui-se que o RDD não viola a Constituição, constituindo forma proporcional de resposta penal em casos graves, que, ao contrário de ofender, concretiza a garantia constitucional da individualização da pena, dentro da liberdade de conformação deixada ao legislador ordinário.

\section{O Princípio da Dignidade da Pessoa Humana.}


A Constituição Federal de 1988 consagra, em seu artigo $1^{\circ}$, nosso perfil políticoconstitucional como sendo um Estado Democrático de Direito. Por assim ser, o Estado Democrático de Direito visa garantir o respeito às liberdades civis, aos direitos humanos e às garantias fundamentais, através do estabelecimento de uma proteção jurídica. Não há a submissão de todos ao império da lei, mas um Estado em que as leis possuem adequação social. Dele, parte um dos principais princípios da nossa Constituição, que é o da Dignidade da Pessoa Humana.

Sendo assim, a carta brasileira insere o princípio da dignidade da pessoa humana como um dos fundamentos da República Federativa do Brasil e o afasta do rol dos direitos fundamentais, previstos no art. $5^{\circ}$ da carta constitucional.

No entendimento de Sarlet (2006) tal deslocamento propositado, demonstra ser esse o princípio que possui a maior carga valorativa e hierárquica de todos os outros princípios reconhecidos no ordenamento brasileiro, com isso, os direitos fundamentais constituem explicitações da dignidade da pessoa humana.

Doravante, definir o conceito de dignidade e até que ponto vai sua aplicação dentro do ordenamento jurídico é tarefa complicada.

Segundo Sarlet (2006), temos que a dignidade é o valor de uma tal disposição de espírito, e está infinitamente acima de todo preço. Nunca ela poderia ser posta em cálculo ou confronto com qualquer coisa que tivesse um preço, sem de qualquer modo ferir a sua sanidade.

Preconiza Zisman (2005) que na linguagem científica, da epistemologia jurídica, que nesse ponto se aproxima do conceito oferecido pela linguagem natural, supra-referido, a dignidade é vista como grandeza, honestidade, decoro e virtude. O homem digno é o homem decente, merecedor, demonstrando a dignidade à aquisição de atributo social e espiritual. $\mathrm{O}$ homem é sujeito de direitos em um âmbito irredutível de autonomia e liberdade, possuindo uma dimensão social que não decorre de pacto histórico, mas da sua própria natureza. Os demais interesses personalíssimos, como o direito à honra, à intimidade, à igualdade, à imagem, à privacidade, dentro outros, decorrem da essencial dignidade que todo ser humano possui. 
A dignidade não é, em si, um direito, porém atributo do ser humano, sendo que o ordenamento jurídico positivado jamais poderá atribuir dignidade a um indivíduo, todavia tem o dever de protegê-la. Consequentemente, a dignidade da pessoa humana inserida no texto da Carta Magna, serviu para o reconhecimento de que o indivíduo não reflete a ordem jurídica, e sim para constituir um objetivo supremo do Estado Democrático de Direito.

É valido, ainda, destacar que não existe direito absoluto, pois, se por um lado há a ampla atuação do princípio da dignidade da pessoa humana - sem qualquer limite -, por outro, nega-se a vigência dos demais direitos. Desse modo, deve o princípio ser ponderado no caso concreto, ao se colidir com outros valores constitucionais.

Assim, sendo o Brasil um Estado Democrático de Direito, os critérios absolutistas, como já mencionado, não são admitidos, para definir os tipos penais e cominar das penas, nem no procedimento dos operadores do direito de adequar a conduta ao fato típico. $\mathrm{O}$ legislador não tem o livre arbítrio para criar crimes. Sob pena de atentar materialmente contra a Constituição, ferindo o princípio da dignidade da pessoa humana, toda norma ou sanção penal que se pretender criar sem a devida adequação social, mediante a aferição de que realmente necessita ser descrita em tipo penal incriminador por representar anseio popular de proteção a bem jurídico, deverá ser imediatamente descartada.

Capez (2014) assinala que um crime, no Estado Democrático de Direito, para assim ser considerado, deve passar por exigências de ordem formal (somente as leis podem descrevê-los e cominar-lhes penas) e material (o seu conteúdo deve ser questionado à luz dos princípios constitucionais do Estado Democrático de Direito). À luz dos princípios decorrentes da dignidade da pessoa humana e do Estado Democrático de Direito, o Direito Penal deve ser legítimo e democrático, descrevendo tipos penais de categoria aberta de modo a ser preenchidos com conteúdo em conformidade com os mencionados princípios.

Nesse sentido, parte-se do pressuposto de que a dignidade da pessoa humana é um constitucional positivo, o qual possui dupla natureza: a de princípio e a de regra. Ao se tratar de um princípio, é passível, mesmo em situações excepcionais, de ponderação com outros princípios e bens jurídicos constitucionais.

Ademais, verifica-se que tal princípio se encontra em diversos outros ramos do direito além do constitucional como, por exemplo, no Direito Penal e Processo Penal. Ou seja, 
ele vem assegurar ao acusado uma pena justa, não admitindo tratamentos cruéis e ofensivos. Todavia, incide não somente no aspecto punitivo, mas também durante a apuração do delito.

\subsection{Dignidade Humana e Direitos Fundamentais.}

A Constituição brasileira de 1988 prescreve em seu artigo $1^{\circ}$ que o Brasil é um Estado Democrático de Direito, e que tem como um dos seus fundamentos, previsto no inciso III, a dignidade da pessoa humana.

Deste modo, o princípio da dignidade da pessoa humana é o fundamento para o estabelecimento e o reconhecimento dos direitos fundamentais, e dá sustentação à aplicação desses direitos, estes recebendo agora especial atenção desse princípio, pois mantém com ele íntima relação de fundamentação e realização.

Assevera Mello (2010), a concretização da dignidade humana ocorre com o reconhecimento dos direitos fundamentais, que devem ser respeitados tanto pelas demais pessoas quanto pelo Estado. Esses direitos realizam o conteúdo da dignidade da pessoa humana juridicamente, na medida em que estabelecem os postulados indispensáveis para que o homem seja tratado e respeitado como fim em si mesmo. Desse modo, a dignidade da pessoa humana é representada, no âmbito jurídico, por uma gama de direitos e garantias fundamentais do ser humano, considerado como tal.

Para Garzón (2006) os direitos humanos ou fundamentais formam parte essencial de um projeto constitucional adequado à concretização das exigências do respeito à dignidade humana. Quando esses direitos têm vigência, impede-se a possibilidade de tratar alguém como um meio. Outorgá-los e respeitá-los não é uma atitude de benevolência por parte de quem detém o poder, mas uma exigência básica em toda sociedade que pretenda ser decente.

Conforme lições de Miranda (2007), pelo menos de modo direto e evidente, os direitos, liberdade e garantias pessoais e os direitos econômicos, sociais e culturais comuns têm a sua fonte ética na dignidade da pessoa de todos os homens. Na verdade, quase todos os direitos acabam remontando à ideia de proteção e desenvolvimento das pessoas

Fazendo um passeio pela Constituição de 1988, há dispositivos que devem ser observados e efetivados pelo Estado brasileiro, tendo como base a dignidade da pessoa humana. Como exemplo, da igualdade de todos perante a lei (artigo $5^{\circ}$, caput); direitos sociais 
previstos no artigo $6^{\circ}$; a valorização do trabalho e a livre iniciativa com a finalidade de assegurar a todos uma existência digna (artigo 170); a ordem social visando a realização da justiça social (artigo 193), entre outros.

O Constituinte de 1988 determinou ao Estado brasileiro o respeito e proteção à dignidade humana e a efetivação dos direitos fundamentais. Não pode o Poder Público se desvincular dessa obrigação.

\subsection{O Princípio da Dignidade da Pessoa Humana e a função punitiva.}

Como se definiu anteriormente, o Estado democrático de direito prima pelas garantias fundamentais do ser humano, fundamentando-se no Princípio da Dignidade da Pessoa Humana.

Desta forma, pode-se dizer que o conceito de dignidade humana reúne um conjunto de valores que não estão restritos, unicamente, à defesa dos direitos individuais do homem, mas também, a outros direitos, de liberdades e de garantias, de interesses que dizem respeito à vida humana, sejam eles sociais, pessoais, políticos, econômicos ou culturais.

Neste diapasão as atitudes do Estado para com a repressão dos infratores devem ser tomadas de forma que não infrinja os princípios constitucionais, como o direito à vida e às condições básicas de sobrevivência de todos os indivíduos, uma vez que infringindo estas condições preconizadas pela Constituição Federal vigente deverá ser declarado como um ato inconstitucional. A Constituição Federal de 1988 preceitua as formas de regularizações políticas e jurídicas, tais quais presentes na parte geral do Código Penal, caracterizando-o como uma ordem jurídica autônoma, porém submetido aos princípios constitucionais, assim como os demais ramos do direito.

Os princípios constitucionais são de demasiada importância, uma vez que não só regulam a ação punitiva do Estado, como garantem os direitos inerentes ao homem.

Ao contrário do que se verifica, a dignidade da pessoa humana e também os direitos humanos não são opostos ao sistema penal e a função punitiva, é um equívoco colocar a ideia humanitária como inimiga da pretensão punitiva, já que essa função do Estado pode se realizar plenamente e alcançar de maneira favorável a sua finalidade, sem ofensa aos valores jurídicos e políticos, que na realidade, nada mais são do que sua base. 
Consequentemente a pena deve ser vista como um instrumento de prevenção do crime e de reações punitivas desmedidas, que permite que o apenado não seja apenas um instrumento de interesses sociais, mas também seja olhado como sujeito da pena, o que lhe garantiria o respeito a sua dignidade enquanto pessoa.

Disso deriva a necessidade de se respeitar, efetivamente, durante a execução da pena todos os direitos e garantias do apenado. Não basta a lei afirmar a condição de humanidade da pena, é preciso que, na prática, a dignidade do preso seja respeitada.

Diante disso, Ferrajoli (2000) entende que é necessário, sobretudo, que as condições de vida dentro da prisão sejam para todos as mais humanas e as menos aflitivas possíveis; que em todas as instituições penitenciárias esteja previsto o trabalho - não obrigatório, senão facultativo - juntamente com o maior número possível de atividades coletivas, de tipo recreativo, cultural, esportiva. Que na vida carcerária se abram e desenvolvam espaços de liberdade e de sociabilidade mediante a mais ampla garantia de todos os direitos fundamentais da pessoa; que, por fim, seja promovida a abertura da prisão - os colóquios, encontros conjugais, permissões, licenças, etc. - não mediante a distribuição de prêmios e privilégios, senão com a previsão de direitos iguais para todos.

Carvalho (2007), defende que sob essa perspectiva, respeitar a proibição da pena de morte, a proibição de penas ou medidas privativas de liberdade perpétuas, a proibição da tortura e tratamento desumano ou degradante, a irretroatividade da lei penal mais gravosa, o direito de defesa, os direitos à vida, liberdade, integridade física e psíquica, significa igualmente promover a dignidade da pessoa humana.

É esta visão, da pena como instrumento de prevenção do crime e de reações punitivas desmedidas, que permite que o apenado não seja apenas um instrumento de interesses sociais, mas também seja olhado como sujeito da pena, o que lhe garantiria o respeito a sua dignidade enquanto pessoa.

\section{O REGIME DISCIPLINAR DIFERENCIADO.}

\subsection{Breve Histórico da Lei de Execuções Penais e Origem do Regime Disciplinar Diferenciado.}

O modelo penitenciário em vigor no Brasil, como é cediço, teve muitos de seus contornos traçados a partir do conjunto de transformações sofridas pela sociedade brasileira 
ao longo do período de exceção democrática, instaurado pela ditadura militar de 1964. Até este momento, só havia disciplinada a Lei no 3.274 de 1957, a qual compilava normas gerais acerca do regime penitenciário.

Findo o ano de 1964, o sistema penitenciário brasileiro retomou com veemência a sua utilidade, com o intuito de reforçar a repressão política e os ideários do regime então vigente. Notadamente, esta época foi estigmatizada por um defensivismo social excessivo e por um combate à periculosidade do indivíduo.

Mas adianta, em 1968, foi promulgado o Decreto $\mathrm{n}^{\circ} 1.162$, o qual deu efeitos mais incisivos ao amplo arbítrio administrativo, bem como recaiu, naturalmente, sobre o regime disciplinar imposto. Nessa época, era aplicado o isolamento preventivo do faltoso, até a aplicação definitiva da reprimenda.

Por conseguinte, uma vez praticada a suposta falta disciplinar, deveria o interno ser conduzido à inspetoria da unidade, na qual caberia ao inspetor decidir por sua segregação preventiva ou não, tendo em conta a gravidade do fato.

Nessa mesma linha de raciocínio do anteprojeto de Roberto Lyra, o regulamento da Guanabara, à época, impôs a reclusão, pelo máximo de 90 (noventa) dias em cela de segurança, que tinha as mesmas dimensões, higiene, aeração, e iluminação da cela comum, porém abastada de instalações sanitárias, cama e colchão.

Assim sendo, quando o gravame segregacionista parecia já ter alcançado o seu ápice com a cela de segurança, surgia a terceira espécie de isolamento: a cela de segurança especial, de evidente cunho retributivo, a qual tinha guarnição compatível com a periculosidade revelada pelo interno.

Feitas essas sintéticas considerações mister ventilar algumas noções acerca da origem e base legal do Regime Disciplinar Diferenciado.

O Regime Disciplinar Diferenciado, instituído pela Lei n. 10.792/2003, permitiu um isolamento mais restrito ao preso envolvido em situações relacionadas à ordem e segurança do estabelecimento prisional ou da sociedade e ainda casos de envolvimento com organizações criminosas, quadrilha ou bando. 
Juliotti (2008), ao discorrer sobre esse tema, afirma que esse regime surgiu da realidade atual do sistema prisional e do dever do Estado de conservar a ordem pública. Esse autor defende que não há irregularidade na sua aplicação, tendo em vista que há regulamentação em lei federal e sua aplicação depende de decisão judicial, com participação do Ministério Público e defesa.

\subsection{Conceito e Hipóteses de Cabimento do Regime Disciplinar Diferenciado.}

O Regime Disciplinar Diferenciado trata-se de um regime que tem como peculiaridade a aplicação de medidas mais severas a alguns presos que se enquadram em grau de periculosidade, e são indisciplinados colocando em risco a segurança da conivência carcerária. O RDD, não é uma forma de cumprimento de pena, pois diferencia dos regimes estabelecidos no código de Processo Penal, quais sejam o regime aberto, semiaberto e fechado.

O Regime Disciplinar Diferenciado ("RDD”) possui natureza de sanção disciplinar, caracterizando-se pela duração máxima de 360 dias, sem que haja prejuízo de sua repetição pela reiteração da prática, até o limite de 1/6 da pena aplicada.

Nesse período, o detento tem direito a visitas semanais de duas pessoas, sem contar as crianças, com duração de duas horas e igual período diário de banho de sol.

Diante dessas características, Mirabete (2004) explica que o RDD não constitui um regime de cumprimento de pena em acréscimo aos regimes fechado, semi-aberto e aberto, nem uma nova modalidade de prisão provisória, mas sim um novo regime de disciplina carcerária especial, caracterizado por maior grau de isolamento do preso e de restrições ao contato com o mundo exterior.

Além disso, os destinatários do "RDD” podem ser presos provisórios e apenados, desde que tenha se verificado a prática de fato previsto como crime doloso, quando da ocorrência de "subversão da ordem ou disciplina interna" (art. 52), ou para aqueles que apresentem alto risco a ordem e a segurança do estabelecimento penal ou da sociedade (art. $52, \S 1^{\circ}$ ) e os condenados sobre os quais recaiam fundadas suspeitas de envolvimento ou participação, a qualquer título, em organizações criminosas, quadrilha ou bando (art. $52, \S 2^{\circ}$ ). 


\subsubsection{Prática de fato previsto como crime doloso que ocasione subversão da ordem ou disciplina internas.}

É de notar que para a configuração dessa hipótese são imprescindíveis dois requisitos concomitantes: a prática de fato previsto como crime doloso e a conturbação da ordem ou disciplina interna do presídio.

Dessa forma, esclarece Mirabete (2004) para o fato que embora configure crime doloso não provoca a subversão da ordem e da disciplina, ou que é previsto como falta grave mas não como crime doloso, ainda que ocasione essa mesma subversão, são aplicáveis as sanções previstas nos incisos III e IV do art. 53.

Através de processo administrativo disciplinar, verificar-se-á a existência ou não desta desordem para fins de requerimento da autoridade administrativa para a inclusão do preso no RDD. Ainda, a submissão do preso a este regime depende de despacho judicial fundamentado, conforme preleciona o artigo 54 da LEP (Lei de Execução Penal).

Ainda dispõe Mirabette (2011) que a Lei $\mathrm{n}^{\circ}$ 10.792, ao criar o regime disciplinar diferenciado, reservou-o como sanção mais gravosa ao preso que pratica fato que, por sua natureza e repercussão, abrange ambas as referidas hipóteses: configura crime doloso e ocasiona a subversão da ordem ou da disciplina do estabelecimento penal.

O artigo 49, parágrafo único, da lei de execução penal alude que se pune a tentativa com a sanção correspondente à falta consumada, ou seja, caso o preso não consiga consumar o crime por circunstâncias alheias a sua vontade, sofrerá as consequências da sanção administrativa como se tivesse concluído o crime. Ainda, para que o preso seja submetido ao RDD, deve ser comprovada a subversão da ordem e disciplina interna do estabelecimento penitenciário.

\subsubsection{Quando o preso coloca em risco a ordem e a segurança do estabelecimento penal ou da sociedade.}

Segundo Luiz Flávio Gomes, essa segunda hipótese é o caso típico do preso que dentro do presídio ou estabelecimento prisional comanda crimes do lado de fora do muro (extra muro), colocando em risco a sociedade e a própria milícia. 


\subsubsection{Recair, sobre o preso, fundadas suspeitas de envolvimento ou participação, a} qualquer título, em organizações criminosas, quadrilha ou bando.

Em outras palavras, se a autoridade administrativa tiver fundadas suspeitas de que algum preso participa de qualquer tipo de organização delinquente, poderá requerer ao Juiz da Execução para que lhe aplique o RDD.

Vale observar que a simples condenação pelo crime previsto no artigo 288 não autoriza, automaticamente, a inclusão no RDD. Ou seja, a lei não exige como pressuposto dessa hipótese a condenação anterior pelo crime de quadrilha ou bando, sendo que a retirada do preso do regime comum somente ocorre quando a sua associação criminosa coloca em risco a segurança da sociedade ou do estabelecimento penal.

Mirabete (2004) esclarece que as hipóteses descritas nas alíneas 2.2.2 e 2.2.3 evidenciam uma inclusão cautelar do preso no RDD, vez que elas têm como finalidade garantir as condições necessárias para que a pena privativa de liberdade ou a prisão provisória seja cumprida em condições que garantam a segurança do estabelecimento penal e a ordem pública, que continuaria ameaçada se, embora custodiado, permanecesse o preso em regime comum.

\subsection{Duração do RDD.}

Por oportuno, saliente-se que o inciso I do artigo 52 da LEP prevê a renovação da sanção disciplinar, em caso de cometimento de nova falta grave de mesma espécie, até o limite de um sexto da pena aplicada. Assim, o RDD tem duração de um ano na primeira ocorrência. Já no caso de reincidência por falta grave, o limite temporal do RDD é de 1/6 da pena efetivamente aplicada, podendo ou não ser superior a 1 ano.

Por fim, o artigo $54, \S 1^{\circ}$, ressalta que a aplicação do RDD depende de requerimento circunstanciado elaborado pelo diretor do estabelecimento ou outra autoridade administrativa, respeitado o contraditório entre Ministério Público e defesa.

Posteriormente, cabe à autoridade judicial prolatar sua decisão fundamentada, dentro do prazo máximo de 15 dias. Interessante observar que o artigo 60 da LEP permite a inclusão preventiva no RDD por dez dias que será, posteriormente, detraído do tempo a ser cumprido por decisão judicial. Essa inclusão preventiva, como ressalva a lei, somente é cabível quando 
o interesse da disciplina e da averiguação do fato assim a exigirem, podendo ser decretada pela própria autoridade administrativa, enquanto aguarda a decisão judicial.

\section{POSIÇÕES DOUTRINÁRIAS SOBRE À IMPLEMENTAÇÃO DO REGIME DISCIPLINAR DIFERENCIADO NO SISTEMA PENITENCIÁRIO BRASILEIRO.}

Pode-se afirmar que o objetivo do legislador ao criar o regime disciplinar diferenciado era separar os líderes das facções criminosas do restante da população carcerária.

Nesse sentido, oportunas são as palavras de Nucci (2006, p. 961) para quem essa nova sanção disciplinar foi concebida a fim de atender às necessidades prementes de combate ao crime organizado e aos líderes de facções que, dentro dos presídios brasileiros, continuam a atuar na condução dos negócios criminosos fora do cárcere, além de incitarem seus comparsas soltos à prática de atos delituosos graves de todos os tipos.

Dessa forma, criou-se a ideia de que a imposição do RDD aumentaria a segurança nos estabelecimentos penais. Seguindo esse raciocínio, a intenção do legislador deveria receber apoio dos operadores de direito. Contudo, a doutrina bem como os julgados acerca da constitucionalidade ou não do RDD, foram divergentes quanto a sua aplicabilidade e legalidade.

\subsection{Da Inconstitucionalidade do RDD.}

Com o a implantação do RDD no Brasil, parte da doutrina, passou a elencar a sua inconstitucionalidade, considerando vários princípios constitucionais.

O Ministro Luiz Vicente Cernicchiiaro, doutor em Direito Penal, quando expôs sua opinião acerca do Regime Disciplinar Diferenciado se mostrou contrário a ele por ser um regime que viola princípios fundamentais, visto que a execução penal está umbilicalmente ligada à lei; isto quer dizer que em sede de execução penal é imprescindível que se respeite os preceitos do direito penal material assim como também os pressupostos do direito processual.

Nenhum ramo do direito está desvinculado do direito constitucional.

No mesmo sentido, o Conselho Nacional de Política Criminal e Penitenciaria (CNPCP), órgão do Ministério da Justiça se manifestou contrário quando analisou o PL $\mathrm{n}^{\circ}$ 5.073/01 que redundou na Lei $n^{\circ} 10.792 / 03$ a qual alterou a LEP inserindo o Regime Disciplinar Diferenciado alegando a máxima que o Regime Disciplinar Diferenciado agride o primado da ressocialização do sentenciado, vigente na consciência mundial desde o iluminismo e pedra angular do sistema penitenciário nacional, inspirado na Escola Nova 
Defesa Social. A LEP, já em seu primeiro artigo traça como objetivo do cumprimento de pena a reintegração social do condenado, a qual é indissociável da efetivação da sanção penal. Portanto, qualquer modalidade de cumprimento de pena em que não haja a concomitância dos dois objetivos legais, o castigo e a reintegração social, com observância apenas do primeiro, mostra-se ilegal e contraria a Constituição Federal.

Com efeito, não é possível conferir interpretação correta da lei se não for levado em conta os princípios que a regem. Na nossa sociedade quando o Estado atua para reprimir as condutas proibidas ele não deve fazê-lo de forma casuística. Seu modo de agir deve nascer de princípios. Não basta apenas a lei repressora estar vigente. Esta lei de ser dotada de aceitação material o que significa obediência aos princípios do Direito principalmente princípios constitucionais.

Dentre eles, há uma discrepância entre a aplicação do RDD com vários o Princípios constitucionais. Senão vejamos.

\subsubsection{Conflito com o Princípio da Dignidade da Pessoa Humana.}

O artigo $1^{\circ}$, inciso III, da Constituição Republicana orienta que o princípio da dignidade da pessoa humana representa um dos fundamentos da República Federativa do Brasil, devendo ser tratada a dignidade com um valor imanente à pessoa humana, tendo em vista ser dotada de espiritualidade e valores que lhe são próprios.

Representado, assim um dos desdobramentos da importância do princípio da dignidade da pessoa humana, princípios como a vedação de tratamento desumano ou degradante encontram fundamentação no que refere o artigo $1^{\circ}$, inciso III, da Constituição da República Federativa do Brasil.

Nesse sentido, Carvalho; Wunderlich, (2004, p. 6) a referida sanção disciplinar é uma determinação desumana de apartação da pessoa presa rotulada como ameaça à segurança nacional ou um método de aniquilamento de personalidades, o que viola a dignidade humana e a integridade física do preso, conforme sintetiza Rômulo de Andrada Moreira (2006), onde disciplina que o texto legal e a Constituição Federal, concluímos com absoluta tranquilidade ser tais dispositivos flagrantemente inconstitucionais, pois no Brasil não poderão ser instituídas penas cruéis (art. 5, XLVII, “e”, CF/88), assegurando-se aos presos (sem qualquer distinção, frise-se) o respeito à integridade física e moral (art. 5º XLIX) e garantindo-se, ainda, que ninguém será submetido a tratamento desumano ou degradante (art. $5^{\circ}$, III). 
Consequentemente, fica claro a ofensa ao Princípio Constitucional da Dignidade da Pessoa Humana, uma vez que o Regime Disciplinar Diferenciado tem como características o recolhimento em cela individual, visitas semanais de apenas duas pessoas, com duração de duas horas e direito à saída de cela por duas horas diárias para banho de sol, tudo isso podendo ocorrer por até trezentos e sessenta dias consecutivos, podendo, inclusive, sofrer novamente a sanção por nova falta grave.

Conforme Fábio Félix Ferreira e Salvador Cutiño Raya (2004, p. 273) estas medidas representam um plus de humilhação e deve receber o título de penal cruel e desumana ou degradante, em função a gravidade da conduta, bem como entendem que isolar uma pessoa durante 360 dias, limitando sua liberdade de movimentos, restringindo extremamente sua comunicações e seu vínculos com o exterior e endurecendo, em geral, todas as suas condições de vida, configura um tratamento degradante, que aumenta desnecessariamente a humilhação que já sofre uma pessoa submetida a uma pena privativa de liberdade, situação mais grave ainda em ambientes onde a realidade das prisões é lamentável, como é o caso brasileiro.

Ademais, restringe ainda mais os direitos não limitados pela sentença penal condenatória. Limita assim o número de visitas contribuindo para dificultar a ressocialização do preso.

Ainda, Ferreira; Raya (2004, p. 273), dá à pena um aspecto cruel desumano e degradante. Na obra Tratamiento peniteciaro y derechos fundamentales ,Iñaki Ribeiera Beiras citado por Fábio Félix leciona o que é tratamento degradante: "há de entenderse como trato degradante aquel que es susceptible de crear em lãs víctimas sentimientos de temor, de angustia y de inferioridad capaces de humillarles, de envilecerles y de quebrantar, em su caso, su resistência física y moral.

De uma forma singela, portanto, pode-se afirmar que pena cruel é aquela que provoca sofrimento intenso e humilhação na pessoa, trazendo consigo uma acentuada ofensa à integridade humana. Cumpre observar que não existe legislação complementar que forneça o conceito preciso de tratamento desumano, cruel ou degradante.

No entanto, como salientado pelo ex-Relator especial das Nações Unidas para a Tortura, Sir Nigel Rodley, o uso do conceito de tortura fornecido pela Convenção Interamericana para Prevenir e Punir Tortura pode ser pensada como abarcadora da maioria de atos que noutros lugares poderiam ser tratados como tratamentos cruéis proibidos ("prohibited ill-treatment") que não chegam a ser tortura. 
Assim, em face da ausência de uma definição precisa de tratamento desumano, cruel ou degradante, utiliza-se o conceito de tortura, uma vez que o mesmo permite afirmar "que, sendo esta um ato extremo, aqueles seriam uma versão mitigada daquela, dada a sua menor intensidade. E, de acordo com a mencionada Convenção, tortura é:

Artigo $2^{\circ}$. [...] todo ato pelo qual são infligidos intencionalmente a uma pessoa penas ou sofrimentos físicos ou mentais, com fins de investigação criminal, como meio de intimidação, como castigo pessoal, como medida preventiva, como pena ou com qualquer outro fim. Entender-se-á também como tortura a aplicação, sobre uma pessoa, de métodos tendentes a anular a personalidade da vítima, ou a diminuir sua capacidade física ou mental, embora não causem dor física ou angústia psíquica. Não estarão compreendidos no conceito de tortura as penas ou sofrimentos físicos ou mentais que sejam unicamente consequiência de medidas legais ou inerentes a elas, contanto que não incluam a realização dos atos ou a aplicação dos métodos a que se refere este artigo.

Além do mais, a Corte Interamericana de Direito humanos considerou que o isolamento prolongado e a redução do número de visitas constituem tratamento cruel e desumano La Corte ha establecido que el "aislamiento prolongado y la incomunicación coactiva son, por sí mismos, tratamientos crueles e inhumanos, lesivos de la integridad psíquica y moral de la persona y del derecho al respeto de la dignidad inherente al ser humano. [...] la incomunicación durante la detención, [...] el aislamiento en celda reducida, sin ventilación ni luz natural, [...] las restricciones al régimen de visitas [...], constituyen formas de tratos crueles, inhumanos o degradantes en el sentido del artículo 5.2 de la Convención Americana.

Portanto, não há que se argumentar no sentido de que entre proteger a dignidade individual da pessoa presa ou proteger a dignidade dos integrantes de toda a sociedade, carcerária, ou não, deve-se optar apenas pela defesa da coletividade, no geral, uma vez que é possível preservar tanto a dignidade da pessoa humana recolhida em estabelecimento prisional, quanto a dignidade dos integrantes de toda a sociedade.

\subsubsection{Conflito com o Princípio da Presunção de Inocência.}


No Brasil, o princípio da presunção de inocência foi positivado no artigo $5^{\circ}$, inciso LVII, que dispõe que ninguém pode ser considerado culpado até o trânsito em julgado da sentença penal condenatória.

Nesse sentido, em uma análise jurídico-formal o regime disciplinar diferenciado não é pena; mas sim uma sanção disciplinar que se encontra delineada na Lei de Execução penal. Sob esta ótica não há falar em ofensa ao princípio constitucional da presunção de inocência. No entanto, muitos pensadores renomados do direito admitem que a lei 10.792 de $1^{\circ}$ de dezembro de 2003 estabeleceu um novo regime de cumprimento de pena não previsto no Código Penal Brasileiro. O regime fechadíssimo. Na forma é sanção disciplinar; materialmente é regime de cumprimento de pena. E, assim se entendendo trata-se de um plus que não estava previsto no momento da sentença penal condenatória a qual definiu a situação jurídica do condenado.

Assim, tratando-se o Regime Disciplinar Diferenciado de forma mais rigorosa de cumprimento de pena, dissimulado no nome de sanção disciplinar, há de se concordar que viola o princípio da presunção de inocência ao submeter o preso provisório, aquele que não teve sentença penal condenatória transitada em julgado, a uma punição disciplinar extremamente rigorosa, podendo chegar a um sexto da pena que sequer foi aplicada.

$\mathrm{Na}$ hipótese do art. $52 \S 2^{\circ}$ da LEP onde a hipótese ensejadora de inclusão para o preso definitivo é baseada em fundadas suspeitas de envolvimento ou participação em organizações criminosas, quadrilha ou bando, também viola o princípio da presunção de inocência ao incluir o preso definitivo no referido regime baseado apenas em fundadas suspeitas, quando no ordenamento jurídico brasileiro o entendimento é de que ninguém será considerado culpado até o trânsito da sentença penal condenatória.

Como já mencionado, no Estado Democrático de Direito vigora o princípio que ninguém será considerado culpado até o trânsito da sentença penal condenatória.

Corroborando o pensamento exposto acima temos a posição de Maria Thereza Rocha de Assis Moura, segundo Carvalho (2007), na qual trata-se, em verdade, de regime fechadíssimo de cumprimento de pena, não previsto pelo Código Penal, razão pela qual viola o princípio da reserva legal, previsto no artigo $5^{\circ}$, XXXIX, da Constituição da República, e a própria legalidade da execução do título judicial, ao submeter o preso provisório, que ainda não foi julgado e condenado, ao Regime Disciplinar Diferenciado de 360 dias, prorrogáveis até $1 / 6$ da pena aplicada (art. 52, $\S 2^{\circ}$, da Lei de Execução Penal), em inequívoco excesso de 
execução. Não há dúvida de que submeter aquele que não foi definitivamente condenado a condições que ferem a dignidade humana, pelo prazo de 1/6 da pena que sequer foi aplicada, constitui insuportável ilegalidade, além de afrontar a garantia constitucional da nãoconsideração prévia de culpabilidade, inserto no artigo $5^{\circ}$, LVII, da Constituição da República.

\subsubsection{Conflito com o Princípio da Legalidade.}

Da mesma forma, grande parte da doutrina entende que as hipóteses de aplicação do RDD violam o Princípio da Legalidade, especificadamente no que se refere à taxatividade das normas penais incriminadoras. De acordo com o mencionado Princípio, o tipo penal deve ser certo, claro, taxativo e prévio. Porém o legislador utilizou expressões vagas que dificultam precisar de forma inequívoca qual a conduta do preso que acarretaria a sua inclusão no RDD.

Oportuna é a lição de Castilho (1988, p. 25) onde importa na reserva legal dos direitos e deveres, das faltas disciplinares e sanções correspondentes, a serem estabelecidos de forma taxativa, à semelhança da previsão de crimes e penas no Direito Penal. As restrições de direitos ficam sob reserva legal, evitando-se o uso de conceitos de sentido aberto.

Neste contexto, os termos contidos no caput do art. 52 e seus parágrafos são vagos, dotados de imprecisão jurídica e podem dar azo a diferentes e paradoxais interpretações jurídicas. São eles: a) subversão da ordem; b) subversão da disciplina; c) alto risco para a ordem e a segurança penal ou da sociedade; d) fundadas suspeitas ; e) organizações criminosas.

\subsubsection{Da Ressocialização do Preso.}

A LEP tem como principal objetivo a ressocialização que consiste em oferecer ao preso, durante o período de cumprimento de sentença ou decisão, possibilidades de retorno ao convívio em sociedade em condições de não retornar ao crime ou outra infração.

Por assim ser, o RDD significa um agravamento qualitativo à pena privativa de liberdade, aumentando o sofrimento imposto aos presos, através de um regime de superreclusão, que representa a maxi punibilidade do Estado. Na redação da Lei 10.792/2003, a prevalência do sentimento de que não basta "apenas" prender, é preciso fazer com que o preso sofra mais, como se esta fosse uma maneira de evitar que este entre em contato com o 
ambiente extra carcerário, garantir a segurança interna do presídio ou mesmo de impedir a corrupção interna no ambiente carcerário.

Logo, a sanção severamente aplicada possui cunho vingativo, pois vislumbra-se que o dispositivo de lei dispõe isolamento por 360 dias, com repetição, se necessário for; recolhimento em cela individual; visitas semanais de duas pessoas por apenas duas horas; direito à saída da cela por duas horas diárias para banho de sol.

Percebe-se, entretanto, que a lei distorce a função ressocializadora da pena, tratando o preso como um "verdadeiro inimigo". A condenação, em uma clara substituição do Direito Penal de fato pelo Direito Penal de autor, passa a ser encarada como uma punição à determinada classe de autores e não ao fato em si. Assim, não importa o que se faz ou omite, mas quem pratica o crime doloso ou a falta e grave, quem representa risco para a ordem e segurança do estabelecimento penal ou da sociedade ou quem é suspeito de envolvimento em organizações criminosas, quadrilhas ou bando. A adoção do RDD viola o princípio da igualdade, na medida em que representa um tratamento diferenciado a certo tipo de autor de delito, classificando os presos em "cidadãos" e "inimigos".

Na contramão da noção de reintegração social que inspirou a Lei de Execução Penal, o Regime Disciplinar Diferenciado aumenta a punição com a ressignificação da disciplina e da segurança. A violação teleológica constitucional da pena é latente, deixando a mesma de ser utilizada como instrumento ressocializador, para representar a força do Estado.

\subsection{Da Constitucionalidade do RDD.}

Inicialmente, a doutrina que sustenta a inconstitucionalidade do RDD, mencionando que a possibilidade de manter um homem solitariamente em uma cela pelo período previsto no RDD (até 360 dias) ofende a vedação a tratamento desumano ou degradante e a impossibilidade de penas cruéis. No entanto, o isolamento, por si, não pode ser considerado inconstitucional, pois quando devidamente justificado em face de seu mau comportamento, não se traduz em pena desumana ou cruel, nem mesmo caracteriza, como defendem alguns defensores da inconstitucionalidade do RDD, violação da integridade física e mental do sujeito preso.

O princípio da legalidade (art. $5^{\circ}, \mathrm{XXXIX),} \mathrm{que} \mathrm{traz} \mathrm{a} \mathrm{previsão} \mathrm{segundo} \mathrm{a} \mathrm{qual} \mathrm{"não}$ há crime sem lei anterior que o defina, nem pena sem prévia cominação legal”, estabelece a necessidade da tipificação certa, clara e taxativa. Ora, o art. 52 da LEP, com a redação dada 
pela Lei 10.792, não contém a abstração referida e, ao contrário da tese supra, estabelece taxativamente as situações que ensejam a adoção do RDD, que a teor do dispositivo assim podem ser resumidas: a) a prática de fato previsto como crime doloso ou que ocasione subversão da ordem ou disciplina internas (art. 52, caput); b) presos nacionais ou estrangeiros que apresentem alto risco para a ordem e a segurança do estabelecimento penal ou da sociedade $\left(\S 1^{\circ}\right)$; c) caso recaiam sobre o preso fundadas suspeitas de envolvimento ou participação, a qualquer título, em organizações criminosas, quadrilha ou bando $\left(\S 2^{\circ}\right)$; d) presos provisórios ou definitivos. Visto isso, não se vislumbra ofensa ao princípio constitucional da legalidade pelo RDD.

Igualmente afasta-se a alegação de inconstitucionalidade do regime diferenciado fundada na alegação de incompatibilidade com o regime de individualização da pena, uma vez que justamente o RDD preserva a individualização da pena, porque impõe a alguns presos, em casos determinados, atendidas as hipóteses legalmente previstas, regime mais rigoroso, garantindo, ainda, a segurança dos demais presos, não se sustentando a alegada ofensa à Constituição.

\section{Conclusão.}

A Constituição Federal de 1988 consagra, em seu artigo 1º, nosso perfil políticoconstitucional como sendo um Estado Democrático de Direito. Por assim ser, o Estado Democrático de Direito visa garantir o respeito às liberdades civis, aos direitos humanos e às garantias fundamentais, através do estabelecimento de uma proteção jurídica. Não há a submissão de todos ao império da lei, mas um Estado em que as leis possuem adequação social. Dele, parte um dos principais princípios da nossa Constituição, que é o da Dignidade da Pessoa Humana.

Deste modo, o princípio da dignidade da pessoa humana é o fundamento para o estabelecimento e o reconhecimento dos direitos fundamentais, e dá sustentação à aplicação desses direitos, estes recebendo agora especial atenção desse princípio, pois mantém com ele íntima relação de fundamentação e realização.

Diante disso deriva a necessidade de se respeitar, efetivamente, durante a execução da pena todos os direitos e garantias do apenado. Não basta a lei afirmar a condição de humanidade da pena, é preciso que, na prática, a dignidade do preso seja respeitada. 
Por assim ser, o Regime Disciplinar Diferenciado, instituído pela Lei n. 10.792/2003, permitiu um isolamento mais restrito ao preso envolvido em situações relacionadas à ordem e segurança do estabelecimento prisional ou da sociedade e ainda casos de envolvimento com organizações criminosas, quadrilha ou bando. Possuindo, assim, natureza de sanção disciplinar, caracterizando-se pela duração máxima de 360 dias, sem que houvesse prejuízo de sua repetição pela reiteração da prática, até o limite de 1/6 da pena aplicada.

Com o a implantação do RDD no Brasil, parte da doutrina, passou a elencar a sua inconstitucionalidade, considerando vários princípios constitucionais.

O primeiro deles foi da Dignidade da Pessoa Humana, onde limitou a vedação de tratamento desumano ou degradante, com fundamento no artigo $1^{\circ}$, inciso III, da Constituição da República Federativa do Brasil.

Ademais, entende-se que viola o Princípio da Legalidade, pois estabeleceu um novo regime de cumprimento de pena não previsto no Código Penal Brasileiro. O regime fechadíssimo.

Sem mencionar a argumentação de contrariedade a função de ressocializar o apenado. Percebe-se, entretanto, que a lei distorce a função ressocializadora da pena, tratando o preso como um "verdadeiro inimigo.

Entretanto, há entendimentos doutrinários que sinalizam para a constitucionalidade da aplicação do RDD, em especial porque entendem que a redação dada pela Lei 10.792, não contém a abstração referida e, estabelece taxativamente as situações que ensejam a adoção do RDD. Igualmente afasta-se a alegação de inconstitucionalidade do regime diferenciado fundada na premissa de incompatibilidade com o regime de individualização da pena, uma vez que justamente o RDD preserva a individualização da pena, porque impõe a alguns presos, em casos determinados, atendidas as hipóteses legalmente previstas, regime mais rigoroso, garantindo, ainda, a segurança dos demais presos, não se sustentando a alegada ofensa à Constituição.

Portanto, a sociedade e o ordenamento jurídico, ainda não encontrou soluções eficazes para a separação de agentes de alto grau de periculosidade, bem como a sua possível ressocialização. Nesse diapasão, o RDD, é o regime que se mostra premente na segurança jurídica. De modo, a preservar os direitos da coletividade. Pelos vários motivos legais 
elencados, entende-se que não é a melhor solução, porém por ora a única. Enquanto, não houver investimentos em políticas publicas eficazes, na qual fomentem a educação, trabalho e efetivo preservação dos direitos fundamentais, estaremos reféns de medidas cada vez mais coercitivas e de caráter segregacional. Frente a isto, o RDD não viola a Constituição, constituindo forma proporcional de resposta penal em casos graves, que, ao contrário de ofender, concretiza a garantia constitucional da individualização da pena, dentro da liberdade de conformação deixada ao legislador ordinário, cuidando-se de hipótese de reserva legal simples, dentro de uma relação de especial sujeição, consistindo em instrumento necessário e adequado frente a certas práticas criminosas.

\section{Referências.}

CAPEZ, Fernando. Curso de Direito Penal, Parte Geral 1, $18^{\circ}$ edição. São Paulo: Saraiva, 2014.

CARVALHO, Salo de (Coord.). Crítica à execução penal. 2. ed. rev., ampl. e atual. de acordo com a Lei 10.792/03, que instituiu o Regime Disciplinar Diferenciado (RDD). Rio de Janeiro: Lúmen Júris, 2007.

CASTILHO, Ela Wiecko V. de. Controle da legalidade na execução penal. Porto Alegre: Sérgio Fabris, 1988.

CORTE Interamericana de Derechos Humanos. Caso Castillo Petruzzi y otros Vs. Peru. Sentencia 30 del mayo de 1999.Disponível em: <http://www.corteidh.or.cr/docs/casos/articulos/seriec_52_esp.doc>. Acesso em: 01 de fev. 2019.

FERRAJOLI, Luigi. Direito e razão: teoria do garantismo penal. São Paulo: Revista dosTribunais, 2000.

FERREIRA, Fábio Félix; RAYA, Salvador Cutiño. Da inconstitucionalidade do isolamento em cela e do regime disciplinar diferenciado. Revista Brasileira de Ciências Criminais, v. 12, n. 49, p. 251290, jul./ago. 2004.

GARZÓN VALDÉS, Ernesto. ¿Cuál es la relevancia moral del principio de la dignidad humana? In; BINDER, Alberto M., et al. Derechos Fundamentales y Derecho Penal. Córdoba: Advocatus, 2006.

MOREIRA, Rômulo de Andrade. O monstro RDD - É melhor chamar de Regime Disciplinar da Desesperança. Revista Consultor Jurídico. Disponível em: Acesso em: 01 fev. 2019.

MELLO, Sebástian Borges de Albuquerque. O conceito material de culpabilidade: o fundamento da imposição da pena a um indivíduo concreto em face da dignidade da pessoa humana. Salvador: Jus Podivm, 2010.

Mirabete, Julio Fabbrini. Execução Penal: comentários à Lei 7.210, de 11 de julho de 1984. 11. ed. São Paulo:Atlas, 2004. 
MIRABETE, Julio Fabbrini, Execução Penal. São Paulo, Atlas, 2011.

MIRANDA, Jorge apud TAVARES, André Ramos. Curso de direito constitucional. 5 ed. rev. e atual. São Paulo: Saraiva, 2007.

NUCCI, Guilherme de Souza. Manual de Processo Penal e Execução Penal. São Paulo: Ed. Revista dos Tribunais, 2006. SARLET, Ingo Wolgang. Dignidade da pessoa humana e direitos fundamentais na Constituição Federall de 1988. 4. Ed. Rev. Ampl. Porto Alegre: Livraria Do Advogado, 2006.

ZISMAN, Célia Rosenthal. O princípio da dignidade da pessoa humana. São Paulo: IOB Thomsom, 2005. 